\begin{tabular}{|l|l|l||}
\hline \multicolumn{2}{|c|}{ PublisherInfo } \\
\hline \hline PublisherName & $:$ & BioMed Central \\
\hline \hline PublisherLocation & $:$ & London \\
\hline \hline PublisherImprintName & $:$ & BioMed Central \\
\hline \hline
\end{tabular}

\title{
Telomerase mutations
}

\begin{tabular}{|l|l|l||}
\hline \multicolumn{2}{|c|}{ ArticleInfo } \\
\hline \hline ArticleID & $:$ & 4214 \\
\hline \hline ArticleDOI & $:$ & $10.1186 /$ gb-spotlight-20011002-01 \\
\hline \hline ArticleCitationID & $:$ & spotlight-20011002-01 \\
\hline \hline ArticleSequenceNumber & $:$ & 285 \\
\hline \hline ArticleCategory & $:$ & Research news \\
\hline \hline ArticleFirstPage & $:$ & 1 \\
\hline \hline ArticleLastPage & $:$ & 2 \\
\hline \hline & & RegistrationDate : 2001-10-02 \\
ArticleHistory & $:$ & OnlineDate $\quad$ 2001-10-02 \\
\hline \hline ArticleCopyright & $:$ & BioMed Central Ltd2001 \\
\hline \hline ArticleGrants & $:$ & \\
\hline \hline ArticleContext & $:$ & 130592211 \\
\hline \hline
\end{tabular}




\section{Jonathan B Weitzman}

Email: jonathanweitzman@hotmail.com

Patients with dyskeratosis congenita suffer from defects in skin, nails, hair and gut, and usually die from bone-marrow failure. An X-linked form of the disease is due to mutations in the DKC1gene that encodes dyskerin, a protein associated with small nucleolar RNAs and telomerase RNA (hTR). In the September 27 Nature, Tom Vulliamy and researchers at Imperial College and the Hammersmith Hospital, London, UK, identify mutations that cause autosomal dominant dyskeratosis congenita (Nature 2001, 413:432-435). A genome-wide scan using 400 microsatellite markers narrowed down the search to chromosome 3q21-3q28 which includes the hTR gene. They found an $821 \mathrm{bp}$ deletion including $74 \mathrm{bp} 3^{\prime}$ of the coding region, and point mutations in some dyskeratosis congenita families. The authors suggest that haplo-insufficiency of hTR accounts for telomere erosion and premature-aging symptoms associated with the dyskeratosis congenita disease.

\section{References}

1. Dyskeratosis congenita in all its forms.

2. Dyskerin; $D K C l$, [http://www.ncbi.nlm.nih.gov:80/entrez/dispomim.cgi?id=300126]

3. Nature, [http://www.nature.com]

4. Imperial College, [http://www.ic.ac.uk]

5. Dyskeratosis congenita, telomeres and human ageing. 